\title{
Pengaruh Promosi dan Kualitas Produk Terhadap Keputusan Pembelian Dimediasi Citra Merek (Studi Pada Konsumen KOI Bubble Tea Tunjungan Plaza Surabaya)
}

\author{
Rani Oktavianti \\ Manajemen, Sekolah Tinggi Ilmu Ekonomi Indonesia (STIESIA) Surabaya \\ Anindhyta Budiarti \\ Manajemen, Sekolah Tinggi Ilmu Ekonomi Indonesia (STIESIA) Surabaya
}

Email: ranioktavianti.oktav@gmail.com

anindhytabudiarti@stiesia.ac.id

\begin{abstract}
Abstrak
KOI Bubble Tea merupakan minuman yang berasal dari Taiwan pada awal tahun 1980. Salah satu perusahaan produk merek minuman yang popular di Seluruh Indonesia dengan mengeluarkan produk andalan yang berupa bola tapioka dan produk lainnya yang telah dikembangkan yaitu berbagai varian rasa dan topping. Penelitian ini bertujuan untuk mengetahui Pengaruh Kualitas Produk dan Promosi terhadap Keputusan Pembelian Dimediasi Citra Merek pada KOI bubble tea. Populasi yang digunakan dalam penelitian merupakan pelanggan KOI bubble tea. Jenis penelitian ini adalah penelitian kuantitatif. Sampel yang diperoleh dalam penelitian ini menggunakan purposive sampling, dimana penentuan sampelnya diperoleh dengan memberikan batasan-batasan kepada responden yang memenuhi kriteria sebagai sumber data. Jumlah sampel yang digunakan dalam penelitian ini sebanyak 100 sampel yang merupakan elanggan KOI bubble tea. Metode analisis yang digunakan adalah analisis jalur (path analysis) dengan menggunakan program SPSS. Hasil penelitian ini menunjukkan bahwa promosi berpengaruh signifikan dan positif terhadap citra merek. Kualitas produk berpengaruh signifikan dan positif terhadap citra merek. Promosi berpengaruh signifikan dan positif terhadap keputusan pembelian. Kualitas produk berpengaruh signifikan dan positif terhadap keputusan pembelian. Citra merek berpengaruh tidak signifikan dan positif terhadap keputusan pembelian. Promosi berpengaruh terhadap keputusan pembelian dimediasi citra merek. Kualitas produk berpengaruh terhadap keputusan pembelian dimediasi citra merek.
\end{abstract}

Kata Kunci: Promosi, Kualitas Produk, Citra Merek, Keputusan Pembelian.

\section{Pendahuluan}

Seiring berkembangnya teknologi yang semakin canggih di era modern ini, banyak perusahaan yang tumbuh dan berkembang pesat. Minuman-minuman substitusi pun mulai bermunculan. Dengan semakin cerdasnya konsumen menimbulkan persaingan yang ketat antar produsen dalam usaha merebutkan perhatian konsumen yang ada di pasar untuk membeli produknya. Sektor dunia usaha telah menjadi suatu persaingan yang ketat bagi perusahaan ataupun dari perseorangan yang terlibat di dalamnya, termasuk usaha di bidang minuman bubble tea. Usaha di bidang minuman bubble tea juga merupakan salah satu bidang usaha yang merupakan banyak diminati dan memiliki pertumbuhan yang baik di kota Surabaya. Pembelian bubble tea menciptakan citra rasa yang digemari oleh para remaja 
milenial karena keinginan. Di samping itu strategis pelayanan yang ramah dari karyawan kepada konsumen memberikan kesan baik serta berfungsi sampai jenjang waktu yang cukup panjang. Oleh karena itu perusahaan melakukan komunikasi kepada konsumen dengan baik untuk dapat menarik minat konsumen agar memutuskan membeli atau menyukai produk ini. Hal ini juga merupakan cara dari perusahaan dalam memberikan kepuasan tersendiri terhadap konsumen yang sudah menggunakan produknya. Konsep produk menyatakan bahwa konsumen akan lebih menyukai produk minuman bubble tea yang menawarkan varian rasa yang disukai oleh para remaja milenial.

Peran promosi dilakukan untuk berkomunikasi, mempengaruhi, dan membujuk serta mengingatkan pelanggan sasaran tentang perusahaan dan bauran pemasaran. Dengan promosi maka produk akan lebih mudah dikenal masyarakat dan mudah mencapai target konsumen. Oleh karena itu promosi sangatlah penting bagi perkembangan sebuah usaha. Hal ini didukung dengan hasil penelitian yang dilakukan oleh Brata et al (2017) menyatakan bahwa promosi berpengaruh signifikan terhadap keputusan pembelian. Kualitas produk merupakan salah satu kunci persaingan diantara pelaku usaha yang ditawarkan kepada konsumen. Kualitas inilah menjadi kunci utama agar produk tersebut dikenal dan dipecayai masyarakat luas. Dengan terjaga kualitas dari suatu produk yang di perdagangkan oleh produsen maka produk tersebut dapat terjual dengan harga serta kualitas yang baik. Sehingga para konsumen akan tetap percaya untuk membeli produk tersebut. Selain itu produk tersebut tetap mendapatkan tempat di pasaran. Hal ini didukung oleh hasil penelitian yang dilakukan oleh Budianto (2019), Nababan (2019) dan Nisa (2020) menjelaskan bahwa kualitas produk memiliki pengaruh positif signifikan terhadap keputusan pembelian.

Citra merek adalah persepsi konsumen tentang suatu merek sebagai refleksi dari asosiasi yang ada pada pikiran konsumen. Citra merek merupakan asosiasi yang muncul dalam benak konsumen ketika mengingat suatu merek tertentu. Hal ini didukung oleh hasil penelitian yang dilakukan oleh Budianto (2019), Nababan (2019), Ayuningtyas (2016) dan Nisa (2020) menyatakan bahwa citra merek berpengaruh signifikan positif terhadap keputusan pembelian. KOI bubble tea merupakan salah satu perusahaan produk merek minuman yang popular di Seluruh Indonesia dengan mengeluarkan produk andalan yang berupa bola tapioka kenyal (boba atau mutiara) dan produk lainnya, yang telah dikembangkan yaitu berbagai varian rasa dan berbagai topping. KOI bubble tea adalah minuman yang berasal dari Taiwan pada awal tahun 1980. Minuman yang digemari remaja milenial dan menjadi best seller dari produk tersebut adalah bubble milk tea dan caramel black tea macchiato. Minuman khas dari KOI bubble tea yaitu sajian teh dikombinasikan dengan krim putih yang dikenal dengan "Macchiato".

Fenomena yang terjadi saat ini adalah banyaknya peminat untuk membeli minuman bubble tea dan sebagian besar pembeli adalah remaja milenial. Hingga saat ini KOI bubble tea telah memiliki 29 cabang di Indonesia, yakni 14 cabang di Jakarta, 5 cabang di Tangerang, 1 cabang di Bekasi, 1 cabang di Bogor, 2 cabang di Bandung, 4 cabang di Surabaya, 2 cabang di Bali, 2 cabang di Makassar, 1 cabang di Batam, dan 1 cabang di Batam.

Berdasarkan uraian latar belakang yang telah dijabarkan diatas, maka penelitian ini bertujuan untuk mengetahui: (1) Apakah ada pengaruh promosi terhadap citra merek pada KOI bubble tea? (2) Apakah ada pengaruh kualitas produk terhadap citra merek pada KOI bubble tea? (3) Apakah ada pengaruh promosi terhadap keputusan pembelian pada KOI bubble tea? (4) Apakah ada pengaruh kualitas produk terhadap keputusan pembelian pada KOI bubble tea? (5) Apakah ada pengaruh citra merek terhadap keputusan pembelian pada KOI bubble tea? (6) Apakah promosi berpengaruh terhadap keputusan pembelian dimediasi 
citra merek pada KOI bubble tea? (7) Apakah kualitas produk berpengaruh terhadap keputusan pembelian dimediasi citra merek pada KOI bubble tea?

Berdasarkan uraian latar belakang yang telah dijabarkan diatas, maka tujuan penelitian ini sebagai berikut: (1) Untuk mengetahui pengaruh promosi terhadap citra merek pada KOI bubble tea. (2) Untuk mengetahui pengaruh kualitas produk terhadap citra merek pada KOI bubble tea. (3) Untuk mengetahui pengaruh promosi terhadap keputusan pembelian pada KOI bubble tea. (4) Untuk mengetahui pengaruh kualitas produk terhadap keputusan pembelian pada KOI bubble tea. (5) Untuk mengetahui apakah citra merek berpengaruh terhadap keputusan pembelian pada KOI bubble tea. (6) Untuk mengetahui apakah promosi berpengaruh terhadap keputusan pembelian dimediasi citra merek pada KOI bubble tea. (7) Untuk mengetahui apakah kualitas produk berpengaruh terhadap pembelian dimediasi citra merek pada KOI bubble tea.

\section{Landasan Teori dan Pengembangan Hipotesis}

\section{Promosi}

Promosi merupakan salah satu variabel dalam bauran pemasaran (marketing mix) yang perlu diperhatikan oleh perusahaan dalam memasarkan produk maupun jasa. Promosi memegang peranan penting dalam menghubungkan jarak antar produsen dengan konsumen. Kegiatan promosi ini tidak bisa dilakukan secara sembarangan karena dapat mempengaruhi kelangsungan hidup perusahaan dalam jangka panjang. Promosi merupakan aktivitas yang mengkomunikasikan keunggulan produk dan membujuk pelanggan sasaran untuk membelinya (Kotler \& Keller, 2016:47).

\section{Kualitas Produk}

Kualitas produk merupakan tingkat baik buruk terhadap produk yang terdiri dari semua faktor yang melekat pada barang dan jasa, sehingga produk memiliki kemampuan untuk digunakan sebagaimana yang diinginkan konsumen terhadap produk tersebut. Kualitas produk adalah kemampuan suatu produk untuk melakukan fungsinya, kemampuan tersebut meliputi daya tahan, keindahan, ketelitian yang dihasilkan, kemudahan dioperasikan dan diperbaiki, atau atribut lain yang berharga pada produk secara keseluruhan (Kotler \& Keller, 2012:347).

\section{Citra Merek}

Menurut Tjiptono (2015:49) mengatakan bahwa citra merek (brand image) adalah pengamatan dan kepercayaan yang digenggam konsumen, seperti yang dicerminkan di asosiasi atau diingatan konsumen. Citra merek tersusun dari asosiasi merek, bahwa asosiasi merek adalah apa saja yang terkait dengan memori terhadap merek. Citra merek adalah "The set of belief held about a particular brand is known asbrand image". Yang artinya kutipan pada halaman sebelumnya adalah sekumpulan keyakinan terhadap suatu merek disebut citra merek (Kotler \& Amstrong, 2014:p.233)

\section{Keputusan Pembelian}

Menurut Kotler \& Amstrong (2011:161) mengatakan bahwa keputusan pembelian adalah perilaku yang timbul karena adanya rangsangan atau hubungan dari pihak lain. Dengan pengertian yang juga kurang lebih sama keputusan pembelian adalah tahap dalam proses pengambilan keputusan pembelian dimana konsumen benar-benar membeli produknya (Kotler \& Amstrong, 2014). Proses keputusan pembelian dimulai apabila konsumen menyadari suatu masalah atau kebutuhan terhadap suatu produk yang diinginkan. 
Oleh karena itu, pengambilan keputusan pembelian konsumen merupakan suatu proses pemilihan salah satu dari beberapa alternatif penyelesaian masalah dengan tindak lanjut yang nyata. Setelah itu konsumen dapat melakukan evaluasi pilihan dan kemudian dapat menentukan sikap yang akan diambil selanjutnya.

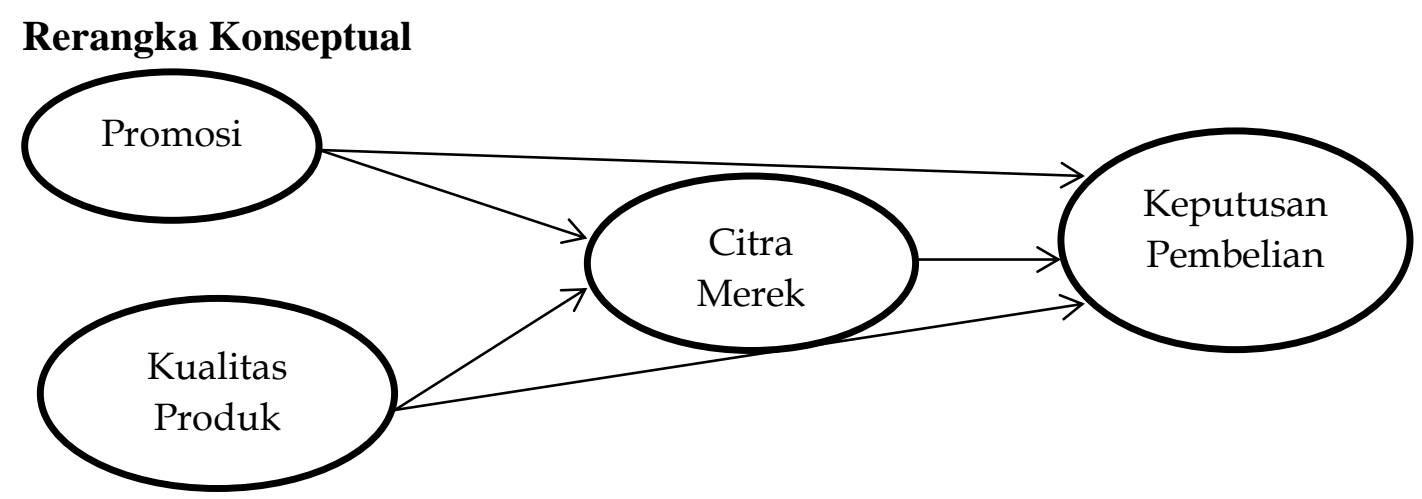

Gambar 1. Model Konseptual (Sumber: Data sekunder diolah, 2021)

\section{Pengembangan Hipotesis}

Penelitian mengenai pengaruh promosi dan kualitas produk terhadap keputusan pembelian melalui citra merek dapat dirumuskan hipotesis sebagai berikut: (H1) Promosi berpengaruh positif signifikan terhadap Citra Merek, (H2) Kualitas Produk berpengaruh positif signifikan terhadap Citra Merek, (H3) Promosi berpengaruh positif signifikan terhadap Keputusan Pembelian, (H4) Kualitas Produk berpengaruh signifikan terhadap Keputusan Pembelian, (5) Citra Merek berpengaruh positif signifikan terhadap Keputusan Pembelian, (6) Promosi berpengaruh positif signifikan terhadap Keputusan Pembelian melalui Citra Merek, (7) Kualitas Produk berpengaruh positif signifikan terhadap Keputusan Pembelian melalui Citra Merek.

\section{Metode Penelitian}

Jenis penelitian yang digunakan dalam penelitian ini yaitu dengan menggunakan metode penelitian kuantitatif korelasional. Penelitian korelasional yaitu dengan karakteristik masalah berupa hubungan korelasional antara dua variabel atau lebih. Tujuannya untuk melihat ada atau tidaknya korelasi antara variabel atau membuat prediksi berdasarkan korelasi antar variabel tersebut. Metode penelitian kuantitatif adalah metode penelitian yang didasarkan pada filsafat positivisme digunakan dalam meneliti sampel dan populasi penelitian. Analisis data yang digunakan bersifat kuantitatif dan bisa diukur dengan tujuan untuk menguji hipotesa yang sudah ditetapkan sebelumnya. Dalam penelitian ini populasi yang digunakan adalah pada Konsumen KOI Bubble Tea di Tunjungan Plaza Surabaya.

Teknik pengambilan sampel yang digunakan dalam penelitian ini yaitu non probability sampling dengan menggunakan teknik purposive sampling. Purposive sampling sebagai teknik yang tidak memberi peluang atau kesempatan yang sama bagi setiap unsur atau anggota populasi untuk dipilih menjadi sampel (Sugiyono, 2015). Pertimbangan untuk memilih teknik pengambilan sampel tersebut dikarenakan akan memilih secara acak pelanggan KOI Bubble Tea tanpa memperhatikan strata atau kriteria lain. 
Jenis data yang digunakan dalam penelitian ini menggunakan metode penelitian kuantitatif, dimana datanya berasal dari penyebaran kuesioner kepada responden. Pengumpulan data dilakukan berdasarkan penyebaran kuesioner, yang bertujuan untuk melakukan survei terhadap objek untuk memperoleh data primer. Kuesioner tersebut akan disebarkan pada Konsumen KOI Bubble Tea di Tunjungan Plaza Surabaya yang pernah membeli dan yang sedang menggunakan produk minuman KOI. Pengukuran yang akan dilakukan pada nilai kuesioner menggunakan skala likert. Skala likert digunakan untuk mengembangkan instrumen mengukur persepsi, sikap dan pendapat individu atau kelompok mengenai fenomena sosial (Sugiyono, 2010).

Data penelitian terkumpul dari 100 responden, kemudian data dianalisis menggunakan analisis jalur adalah dari model regresi. Model diagram jalur (path analysis) pada penelitian ini yaitu:

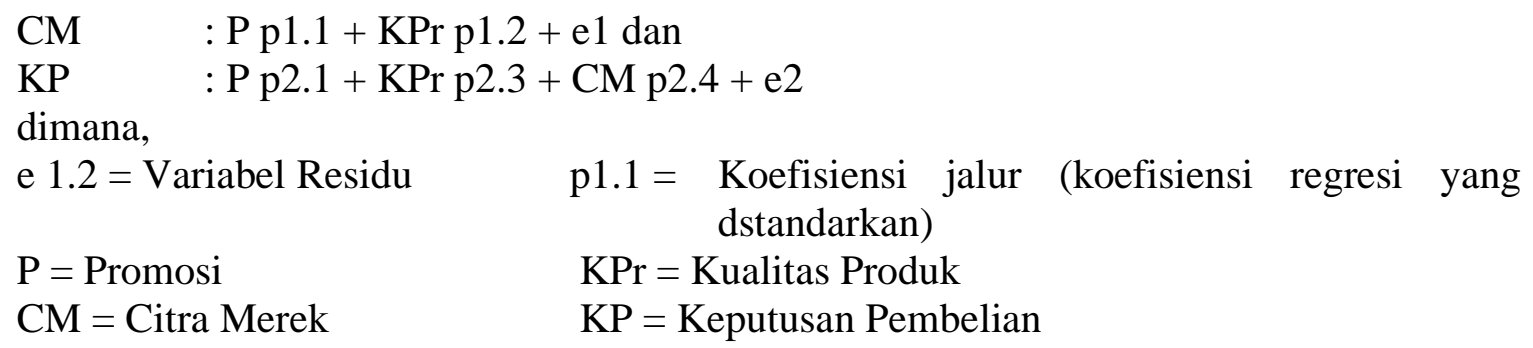

\section{Definisi Operasional Variabel}

Objek dalam penelitian ini yaitu pengetahuan tentang promosi, kualitas produk, citra merek, dan keputusan pembelian. Definisi operasional masing-masing variabel dalam penelitian ini yaitu:

Tabel 1. Definisi Operasional Variabel

\begin{tabular}{|c|l|l|}
\hline No. & \multicolumn{1}{|c|}{ Variabel } & \multicolumn{1}{c|}{ Definisi Operasional } \\
\hline 1. & Promosi & $\begin{array}{l}\text { Tolak ukur seberapa baik pesan promosi dilakukan dan } \\
\text { disampaikan kepada pelanggan KOI bubble tea, media yang } \\
\text { digunakan oleh perusahaan guna untuk melaksanakan promosi } \\
\text { kepada pelanggan KOI bubble tea, jangka waktu yang } \\
\text { dilakukan oleh perusahaan terhadap pelanggan KOI bubble tea } \\
\text { dalam melakukan suatu promosi. }\end{array}$ \\
\hline 2. & Kualitas Produk & $\begin{array}{l}\text { Bentuk produk dari minuman KOI bubble tea meliputi } \\
\text { beberapa ukuran gelas, bentuk atau penampilan, struktur fisik } \\
\text { produk. }\end{array}$ \\
\hline 3. & Citra Merek & $\begin{array}{l}\text { Persepsi dan keyakinan yang dilakukan oleh konsumen, } \\
\text { menambahkan bahwa KOI bubble tea merupakan syarat dari } \\
\text { merek yang kuat dan citra adalah persepsi yang relatif } \\
\text { konsisten dalam jangka panjang. }\end{array}$ \\
\hline 4. & Keputusan Pembelian & $\begin{array}{l}\text { Adanya kebutuhan konsumen dalam keputusan pembelian } \\
\text { akan suatu produk pada pelanggan KOI bubble tea, timbulnya } \\
\text { keinginan konsumen terhadap suatu produk KOI bubble tea, } \\
\text { daya beli yang dimilki konsumen untuk mempertimbangkan } \\
\text { harga yang terjangkau. }\end{array}$ \\
\hline
\end{tabular}




\section{Pembahasan}

Uji Validitas digunakan untuk sebagai menghitung koefisien dan korelasi dari tiaptiap pertanyaan dengan skor total yang diperoleh kemudian dibandingkan dengan angka kritis $\mathrm{r}$ product moment dengan $\mathrm{r}$ hitung. Jika korelasi antara item dengan total skor mempunyai nilai signifikansi $<0.05$ menunjukkan bahwa suatu pertanyaan-pertanyaan tersebut sudah valid sebagai bentuk indikatornya, maka indikator tersebut valid untuk mengukur konstruk yang dimaksud. Uji validitas dalam penelitian ini menggunakan dua tahap. Tahap pertama adalah menguji validitas pada sampel kecil sejumlah 19 sampel. Hasil uji validitas pada sampel kecil menunjukkan bahwa seluruh item pertanyaan dalam kuesioner penelitian ini valid. Tahap kedua uji validitas dilakukan untuk seluruh sampel yang berjumlah 100 responden. Penyebaran kuesioner yang dilakukan pada Konsumen KOI Bubble Tea Tunjungan Plaza Surabaya.

Tabel 1. Hasil Uji Validitas

\begin{tabular}{|c|c|c|c|c|}
\hline Variabel & Indikator & $\begin{array}{l}\text { Corrected Item-total } \\
\text { Correlation (r } \mathbf{r}_{\text {hitung) }}\end{array}$ & $\mathbf{r}_{\text {tabel }}$ & Keterangan \\
\hline \multirow[t]{4}{*}{ Promosi } & $\mathrm{P} 1$ & 0,719 & & Valid \\
\hline & $\mathrm{P} 2$ & 0,644 & & Valid \\
\hline & $\mathrm{P} 3$ & 0,707 & & Valid \\
\hline & $\mathrm{P} 4$ & 0,513 & & Valid \\
\hline \multirow[t]{9}{*}{ Kualitas produk } & KPr1 & 0,717 & & Valid \\
\hline & $\mathrm{KPr} 2$ & 0,612 & & Valid \\
\hline & KPr3 & 0,670 & & Valid \\
\hline & $\mathrm{KPr} 4$ & 0,670 & & Valid \\
\hline & KPr5 & 0,640 & 0,1654 & Valid \\
\hline & KPr6 & 0,626 & & Valid \\
\hline & KPr7 & 0,697 & & Valid \\
\hline & KPr8 & 0,755 & & Valid \\
\hline & KPr9 & 0,491 & & Valid \\
\hline \multirow[t]{3}{*}{ Citra merek } & CM1 & 0,765 & & Valid \\
\hline & $\mathrm{CM} 2$ & 0,775 & & Valid \\
\hline & CM3 & 0,759 & & Valid \\
\hline \multirow[t]{3}{*}{ Keputusan pembelian } & KP1 & 0,601 & & Valid \\
\hline & $\mathrm{KP} 2$ & 0,775 & & Valid \\
\hline & KP3 & 0,831 & & Valid \\
\hline
\end{tabular}

(Sumber: Data sekunder diolah, 2021)

Dari hasil Tabel 1 menunjukkan bahwa nilai dari 19 item seluruh pernyataan instrumen memiliki nilai lebih besar dari taraf signifikan sebesar 0,1654 maka dinyatakan valid dan bisa dipakai untuk analisis selanjutnya.

Uji Reliabilitas menunjukkan sejauh mana hasil pengukuran dengan alat tersebut dapat dipercaya. Suatu konstruk atau variabel dikatakan reliabel dan dapat diterima jika memberikan nilai Cronbach's Alpha >0,6. 
Tabel 2. Hasil Uji Reliabilitas

\begin{tabular}{|l|c|c|}
\hline \multicolumn{1}{|c|}{ Variabel } & Cronbach's Alpha & Keterangan \\
\hline Promosi & 0,641 & Reliabel \\
\hline Kualitas Produk & 0,833 & Reliabel \\
\hline Citra Merek & 0,649 & Reliabel \\
\hline Keputusan Pembelian & 0,682 & Reliabel \\
\hline
\end{tabular}

(Sumber: Data sekunder diolah, 2021)

Berdasarkan pada Tabel 2 menunjukkan bahwa uji reliabilitas dilakukan terhadap item pertanyaan yang dinyatakan valid. Suatu variabel dikatakan reliabel atau handal jika jawaban terhadap pertanyaan selalu konsisten.

\section{Uji Kelayakan Model}

\section{Pengujian Uji F}

Pengujian koefisien regresi secara menyeluruh menggunakan uji $\mathrm{F}$ dengan derajat kebebasan $(\mathrm{df})=\mathrm{n}-\mathrm{k}-1$, pada tingkat kepercayaan $95 \%$ dan $\alpha=0,05$ atau $5 \%$.

Tabel 3. Hasil Uji F Model 1 \& 2

\begin{tabular}{llll}
\hline Model & Variabel & F & Sig. \\
\hline 1 & P-KPr-CM & 31,430 & $0,000^{\mathrm{b}}$ \\
2 & P-KPr-KP & 25,898 & $0,000^{\mathrm{b}}$ \\
\hline
\end{tabular}

(Sumber: Data sekunder diolah, 2021)

Berdasarkan Model 1 diketahui bahwa signifikan hasil uji $\mathrm{F}$ sebesar $0,000<0,05$ berarti menunjukkan penelitian ini dapat digunakan dan diketahui adanya pengaruh antara promosi dan kualitas produk yang berpengaruh signifikan terhadap citra merek sedangkan Model 2 diketahui bahwa signifikan hasil uji $\mathrm{F}$ sebesar $0,000<0,05$ berarti menunjukkan penelitian ini dapat digunakan dan diketahui adanya pengaruh antara promosi dan kualitas produk yang berpengaruh signifikan terhadap keputusan pembelian untuk itu penelitian ini dapat digunakan.

Tabel 4. Hasil Koefisien Determinasi Model 1 \& 2

\begin{tabular}{lll}
\hline Model & Variabel & R Square \\
\hline 1 & P-KPr-CM & 0,393 \\
2 & P-KPr-KP & 0,447 \\
\hline
\end{tabular}

(Sumber: Data sekunder diolah, 2021)

Berdasarkan pada Tabel 4 berdasarkan Model 1 mempunyai R Square sebesar 0,393 dan apabila dirubah menjadi persentase sebesar 39,3\%, artinya pada variabel dependen yakni citra merek dapat dijelaskan oleh variabel independen seperti promosi dan kualitas produk, namun sisanya 60,7 \% dapat dijelaskan pada faktor variabel lain sedangkan Model 2 mempunyai R Square sebesar 0,447 dan apabila dirubah menjadi persentase sebesar 44,7 \%, artinya pada variabel dependen yakni keputusan pembelian dapat dijelaskan oleh variabel 
independen seperti promosi dan kualitas produk, namun sisanya 55,3\% dapat dijelaskan pada faktor variabel lain.

\section{Uji Asumsi Klasik}

\section{Uji Normalitas}
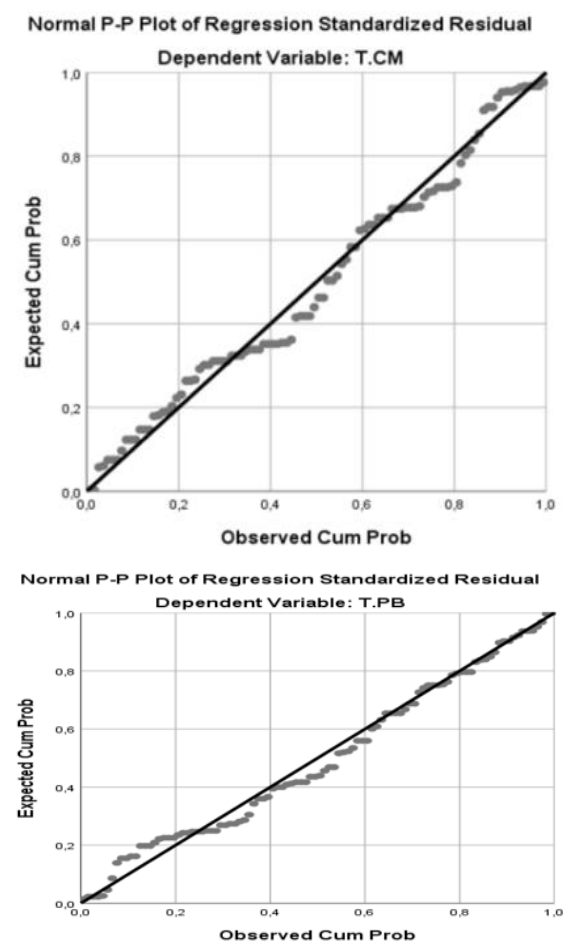

Gambar 1. Hasil Grafik Uji Normalitas Model 1 \& 2

(Sumber: Data sekunder diolah, 2021)

Jika penyebaran data (titik) di sekitar sumbu diagonal dan mengikuti arah garis diagonal, maka model regresi memenuhi asumsi Normalitas. Dari grafik di atas dapat diketahui data telah mengikuti garis diagonal antara 0 (nol) dengan pertemuan sumbu Y (Expected Cum. Prob.) dengan sumbu X (Observed Cum. Prob.). Hal tersebut menunjukkan bahwa data dalam penelitian ini telah berdistribusi normal. Dapat disimpulkan bahwa baik melalui pendekatan Kolmogorov Smirnov maupun grafik model regresi telah memenuhi asumsi normalitas.

Tabel 5. Hasil Uji Multikolineritas Model 1

\begin{tabular}{llll}
\hline Variabel & VIF & Tolerance & Keterangan \\
\hline $\begin{array}{l}\text { Promosi } \\
\text { Multikolineritas }\end{array}$ & 1,664 & 0,601 & Bebas \\
$\begin{array}{l}\text { Kualitas Produk } \\
\text { Multikolineritas }\end{array}$ & 1,664 & 0,601 & Bebas \\
\hline
\end{tabular}

(Sumber: Data sekunder diolah, 2021) 
INOBIS: Jurnal Inovasi Bisnis dan Manajemen Indonesia

Volume 05, Nomor 01, Desember 2021

Rani Oktavianti, Anindhyta Budiarti

Tabel 6. Hasil Uji Multikolineritas Model 2

\begin{tabular}{llll}
\hline Variabel & VIF & Tolerance & Keterangan \\
\hline $\begin{array}{l}\text { Promosi } \\
\text { Multikolineritas }\end{array}$ & 1,819 & 0,550 & Bebas \\
$\begin{array}{l}\text { Kualitas Produk } \\
\text { Multikolineritas }\end{array}$ & 1,911 & 0,523 & Bebas \\
$\begin{array}{l}\text { Citra Merek } \\
\text { Multikolineritas }\end{array}$ & 1,648 & 0,607 & Bebas \\
\hline
\end{tabular}

(Sumber: Data sekunder diolah, 2021)

Menurut hasil pada tabel 6 dan tabel 7 di atas dapat disimpulkan bahwa besarnya nilai Value Influence Factor (VIF) pada seluruh variabel bebas yang dijadikan model penelitian ini bernilai $\leq 10$ serta nilai angka Tolerance hampir mencapai angka 1 maka hasil yang diperoleh telah sesuai dengan ketentuan yang telah ditetapkan, yang dimana hasil dari persamaan regresi tidak ditemukan adanya korelasi antar variabel bebas atau dapat disebut dengan bebas Multikolineritas, sehingga variabel tersebut dapat digunakan dalam penelitian.

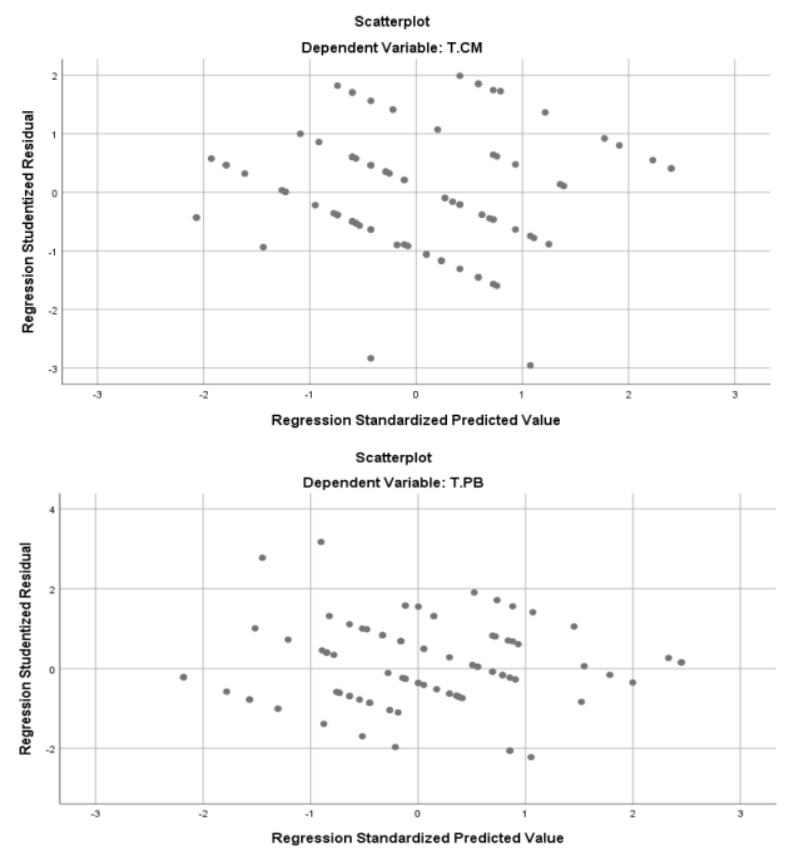

Gambar 2. Hasil Grafik Heteroskedastisitas Model 1 \& 2 (Sumber: Data sekunder diolah, 2021)

Dari Tabel 8 di atas, terlihat titik-titik yang menyebar secara acak dan tidak membentuk sebuah pola yang jelas. Titik-titik tersebut tersebar di atas maupun dibawah angka 0 pada sumbu Y, bahwa disimpulkan tidak terjadi gangguan heteroskesdasititas pada model 1 dan 2 . 


\section{Analisis Jalur}

\section{Penyajian Path Diagram Model Penelitian}

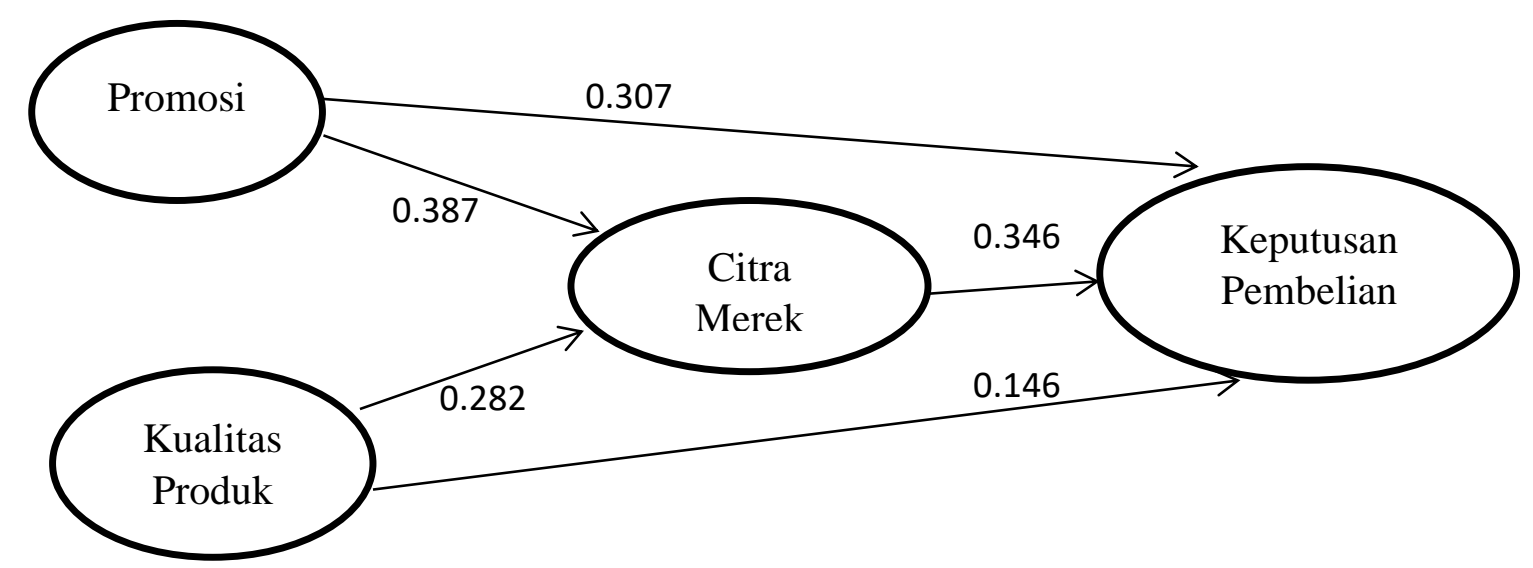

Gambar 3. Analisis Diagram Jalur (Sumber: Data sekunder diolah, 2021)

Pada tabel 9 menunjukkan besaran nilai koefisien jalur untuk masing-masing variabel dependen. Dengan demikian, persamaan sub-struktur untuk diagram jalur di atas dapat diformulasikan sebagai berikut:

$$
\begin{aligned}
& \mathrm{CM}=0,307 \mathrm{P}+0,387 \mathrm{KPr}+\mathrm{e} 1 \ldots \ldots \ldots \ldots \ldots \ldots \\
& \mathrm{KP}=0,346 \mathrm{P}+0,282 \mathrm{KPr}+0,146 \mathrm{CM}+\mathrm{e} 2
\end{aligned}
$$

Dari persamaan model 1 dan model 2 pada persamaan di atas, analisis standardized coefficient untuk masing-masing model dapat dijelaskan sebagai berikut:

Pada persamaan model 1, nilai standardized coefficient untuk variabel Promosi positif sebesar 0,307 menunjukkan adanya hubungan yang searah. Yang berarti, jika Promosi meningkat maka variabel Citra Merek menjadi meningkat dengan asumsi variabel lain konstan. Selanjutnya besarnya standardized coefficient untuk variabel Kualitas Produk positif sebesar 0,387 menunjukkan adanya hubungan yang searah. Yang berarti, jika Kualitas Produk meningkat maka variabel Citra Merek menjadi meningkat dengan asumsi variabel lain konstan. Pada model 1 diketahui variabel Kualitas Produk memiliki pengaruh lebih besar terhadap variabel Citra Merek, karena memiliki nilai standardized coefficient paling tinggi.

Pada persamaan model 2, nilai standardized coefficient untuk variabel Promosi positif sebesar 0,346 menunjukkan adanya hubungan yang searah. Yang berarti, jika Promosi meningkat maka variabel Keputusan Pembelian juga meningkat dengan asumsi variabel lain konstan. Pada model 2 diketahui variabel Promosi paling berpengaruh terhadap variabel Keputusan Pembelian, karena memiliki nilai standardized coefficient paling tinggi. Nilai standardized coefficient untuk variabel Kualitas Produk positif sebesar 0,282 menunjukkan adanya hubungan yang searah. Yang berarti, jika Kualitas Produk meningkat maka variabel Keputusan Pembelian menjadi meningkat dengan asumsi variabel lain konstan. Selanjutnya besarnya nilai standardized coefficient untuk variabel Citra Merek positif sebesar 0,146 menunjukkan adanya hubungan yang searah. Yang berarti, jika Citra Merek meningkat maka variabel Keputusan Pembelian menjadi meningkat dengan asumsi variabel lain konstan. 


\section{Uji Hipotesis (Uji t)}

Pengujian ini dilakukan untuk meninjau sejauh mana pengaruh langsung dari masingmasing variabel independen secara individu terhadap variabel dependen.

Tabel 7. Hasil Uji Hipotesis (Uji t)

\begin{tabular}{|c|c|c|c|c|c|}
\hline Hipotesis & $\begin{array}{l}\text { Hubungan } \\
\text { Variabel }\end{array}$ & $\begin{array}{l}\text { Standardized } \\
\text { Coefficient }\end{array}$ & $\begin{array}{l}\text { Sig- } \\
\text { Value }\end{array}$ & Sig. $\alpha$ & Putusan* \\
\hline $\begin{array}{l}1 \\
\text { Signifikan }\end{array}$ & $\mathrm{P} \rightarrow \mathrm{CM}$ & 0,307 & 0,003 & 0,05 & Positif - \\
\hline $\begin{array}{l}2 \\
3\end{array}$ & $\begin{array}{l}\mathrm{KPr} \longrightarrow \mathrm{CM} \\
\mathrm{P} \longrightarrow \mathrm{KP}\end{array}$ & $\begin{array}{l}0,387 \\
0,346\end{array}$ & $\begin{array}{l}0,000 \\
0,001\end{array}$ & $\begin{array}{l}0,05 \\
0,05\end{array}$ & $\begin{array}{l}\text { Positif - Signifkan } \\
\text { Positif - }\end{array}$ \\
\hline Signifikan & & & & & \\
\hline $\begin{array}{l}4 \\
\text { Signifikan }\end{array}$ & $\mathrm{KPr} \longrightarrow \mathrm{KP}$ & 0,282 & 0,008 & 0,05 & Positif - \\
\hline $\begin{array}{l}5 \\
\text { Signifikan }\end{array}$ & $\mathrm{CM} \longrightarrow \mathrm{KP}$ & 0,146 & 0,138 & 0,05 & Positif - Tidak \\
\hline
\end{tabular}

(Sumber: Data sekunder diolah, 2021)

Hasil pengujian hipotesis penelitian yang ditunjukkan pada tabel 10 dapat dijelaskan secara runtut sebagai berikut:

Pengujian hipotesis 1: Terdapat Pengaruh Promosi terhadap Citra Merek, Pengaruh Promosi terhadap Citra Merek menghasilkan nilai koefisien (Standardized Coefficient) positif sebesar 0,307 dan Sig-value sebesar 0,003. Oleh karena itu menurut ketentuan yang telah ditetapkan bahwa Sig-value 0,003< Sig. tolerance 0,05 maka $\mathrm{Ha}$ diterima, maka terbukti adanya pengaruh yang signifikan antara Promosi (P) terhadap Citra Merek (CM). Dengan demikian $\mathrm{Ha}$ yang diajukan "Promosi terdapat pengaruh terhadap Citra Merek" mendapat dukungan dalam penelitian ini dengan arah pengaruh yang positif.

Pengujian hipotesis 2: Terdapat Pengaruh Kualitas Produk terhadap Citra Merek, Pengaruh Kualitas Produk terhadap Citra Merek menghasilkan nilai koefisien (Standardized Coefficient) positif sebesar 0,387 dan Sig-value sebesar 0,000. Oleh karena itu menurut ketentuan yang telah ditetapkan bahwa Sig-value 0,000 < Sig. tolerance 0,05 maka $\mathrm{Ha}$ diterima, maka terbukti adanya pengaruh yang signifikan antara Kualitas Produk (KPr) terhadap Citra Merek (CM). Dengan demikian $\mathrm{Ha}$ yang diajukan "Kualitas Produk terdapat pengaruh terhadap Citra Merek" mendapat dukungan dalam penelitian ini dengan arah pengaruh yang positif.

Pengujian hipotesis 3: Terdapat Pengaruh Promosi terhadap Keputusan Pembelian, Pengaruh Promosi terhadap Keputusan Pembelian menghasilkan nilai koefisien (Standardized Coefficient) positif sebesar 0,346 dan Sig-value sebesar 0,001. Oleh karena itu menurut ketentuan yang telah ditetapkan bahwa Sig-value 0,001 < Sig. tolerance 0,05 maka $\mathrm{Ha}$ diterima, maka terbukti adanya pengaruh yang signifikan antara Promosi (P) terhadap Keputusan Pembelian (KP). Dengan demikian $\mathrm{Ha}$ yang diajukan "Promosi terdapat pengaruh terhadap Keputusan Pembelian" mendapat dukungan dalam penelitian ini dengan arah pengaruh yang positif.

Pengujian hipotesis 4: Terdapat Pengaruh Kualitas Produk terhadap Keputusan Pembelian, Pengaruh Kualitas Produk terhadap Keputusan Pembelian menghasilkan nilai koefisien (Standardized Coefficient) positif sebesar 0,282 dan Sig-value sebesar 0,008. Oleh karena itu menurut ketentuan yang telah ditetapkan bahwa Sig-value 0,008 < Sig. tolerance 
0,05 maka $\mathrm{Ha}$ diterima, maka terbukti adanya pengaruh yang signifikan antara Kualitas Produk (KPr) terhadap Keputusan Pembelian (KP). Dengan demikian $\mathrm{Ha}$ yang diajukan "Kualitas Produk terdapat pengaruh terhadap Keputusan Pembelian" mendapat dukungan dalam penelitian ini dengan arah pengaruh yang positif.

Pengujian hipotesis 5: Terdapat pengaruh Citra Merek terhadap Keputusan Pembelian, Pengaruh Citra Merek terhadap Keputusan Pembelian menghasilkan nilai koefisien (Standardized Coefficient) positif sebesar 0,146 dan Sig-value sebesar 0,138. Oleh karena itu menurut ketentuan yang telah ditetapkan bahwa Sig-value 0,138 > Sig. tolerance 0,05 maka $\mathrm{Ha}$ ditolak, maka terbukti adanya pengaruh yang tidak signifikan antara Citra Merek (CM) terhadap Keputusan Pembelian (KP). Dengan demikian $\mathrm{Ha}$ yang diajukan "Citra Merek terdapat pengaruh terhadap Keputusan Pembelian" tidak mendapat dukungan dalam penelitian ini dengan arah pengaruh yang positif.

Pengujian hipotesis 6: Terdapat pengaruh Promosi terhadap Keputusan Pembelian dimediasi Citra Merek. Berdasarkan hasil pengujian hipotesis penelitian pada tabel di atas, Promosi (P) memiliki pengaruh yang positif terhadap Citra Merek (CM) dan Citra Merek (CM) berpengaruh positif tidak signifikan terhadap Keputusan Pembelian (KP). Diketahui besarnya pengaruh langsung antara Promosi (P) terhadap Keputusan Pembelian (KP) sebesar 0,346. Sedangkan untuk mengetahui besarnya pengaruh tidak langsung, maka dapat dilakukan perkalian antara nilai beta Promosi (P) terhadap Citra Merek $(\mathrm{CM})$ dan nilai beta Citra Merek (CM) terhadap Keputusan Pembelian (KP) yaitu : 0,307 x 0,146=0,044. Maka pengaruh total yang diberikan Promosi $(\mathrm{P})$ terhadap Keputusan Pembelian (KP) dapat diketahui dengan menjumlah pengaruh langsung dan pengaruh tidak lang sung yaitu : 0,346 + $0,044=0,39$. Dengan demikian dapat diketahui bahwa besarnya pengaruh langsung adalah 0,346 dan besarnya pengaruh tidak langsung adalah 0,39 yang berarti pengaruh tidak langsung lebih besar dibandingkan dengan pengaruh langsung, sehingga secara tidak langsung Promosi $(\mathrm{P})$ berpengaruh signifikan terhadap Keputusan Pembelian (KP) melalui Citra Merek (CM).

Pengujian hipotesis 7: Terdapat Pengaruh Kualitas Produk terhadap Keputusan Pembelian dimediasi Citra Merek. Berdasarkan hasil pengujian hipotesis penelitian pada tabel di atas, Kualitas Produk (KPr) memiliki pengaruh yang positif terhadap Citra Merek (CM) dan Citra Merek (CM) berpengaruh positif tidak signifikan terhadap Keputusan Pembelian (KP). Diketahui besarnya pengaruh langsung antara Kualitas Produk (KPr) terhadap Keputusan Pembelian (KP) sebesar 0,282. Sedangkan untuk mengetahui besarnya pengaruh tidak langsung, maka dapat dilakukan perkalian antara nilai beta Kualitas Produk (KPr) terhadap Citra Merek (CM) dan nilai beta Citra Merek (CM) terhadap Keputusan Pembelian (KP) yaitu : 0,387 x $0,146=0,056$. Maka pengaruh total yang diberikan Kualitas Produk (KPr) terhadap Keputusan Pembelian (KP) dapat diketahui dengan menjumlah pengaruh langsung dan pengaruh tidak langsung yaitu : 0,282 +0,056 =0,338. Dengan demikian dapat diketahui bahwa besarnya pengaruh langsung adalah 0,282 dan besarnya pengaruh tidak langsung adalah 0,338 yang berarti pengaruh tidak langsung lebih besar dibandingkan dengan pengaruh langsung, sehingga secara tidak langsung Kualitas Produk (KPr) berpengaruh signifikan terhadap Keputusan Pembelian (KP) melalui Citra Merek (CM). 


\section{PEMBAHASAN}

\section{Pengaruh Promosi terhadap Citra Merek}

Variabel promosi berpengaruh positif dan signifikan terhadap citra merek pada KOI bubble tea. Hal ini terbukti bahwa promosi semakin meningkatkan citra merek, Promosi mudah dikenali oleh remaja milenial khususnya mahasiswa. Produk KOI memiliki promosi yang akan membuat para pelanggan merasa puas. KOI mempunyai nama di kalangan Internasional karena produk minuman tesebut banyak disukai oleh para remaja dan mempunyai ciri khas rasa yang berbeda. Promosi digunakan untuk mengkomunikasikan keunggulan dan membujuk pelanggan sasaran untuk membelinya (Kotler dan Keller 2016:47). Di samping itu strategis pelayanan yang ramah dari karyawaan kepada pelanggan memberikan kesan baik. Oleh karena itu perusahaan melakukan komunikasi kepada pelanggan dengan baik.

Hasil penelitian ini didukung oleh Budianto (2019) yang dimana penulis meneliti tentang promosi dan kualitas produk terhadap keputusan pembelian melalui brand image menyatakan bahwa promosi dan kualitas produk berpengaruh positif dan signifikan terhadap brand image. Sedangkan Ayuningtyas (2016) menyatakan bahwa promosi berpengaruh positif signifikan terhadap citra merek.

\section{Pengaruh Kualitas Produk terhadap Citra Merek}

Hasil pengujian menunjukan variabel kualitas produk memiliki pengaruh positif dan signifikan terhadap citra merek pada KOI bubble tea, Hal ini terbukti bahwa kualitas produk KOI semakin meningkatkan citra merek. Kualitas produk KOI bubble tea terbukti mempunyai kinerja sistem operasi yang baik dan produk tersebut sangat layak diapresiasi karena semua produk yang dikeluarkan memiliki kualitas yang bagus, selain itu mempunyai tingkat ketahanan pada citra merek tersebut. Kualitas produk menurut Kotler dan Keller (2016:164) kualitas produk adalah kemampuan suatu barang untuk memberikan hasil atau kinerja yang sesuai bahkan melebihi dari apa yang diinginkan pelanggan. Setiap perusahaan yang menginginkan dapat memenuhi kebutuhan dan keinginan pelanggan, maka akan berusaha membuat produk yang berkualitas, yang ditampilkan baik melalui bentuk design produk maupun inti (core) produk itu sendiri.

Hasil penelitian ini didukung penelitian yang dilakukan oleh Budianto (2019), Anjani (2019), Nababan (2019), dan Fitria (2018) menyatakan bahwa kualitas produk berpengaruh positif signifikan terhadap citra merek.

\section{Pengaruh Promosi terhadap Keputusan Pembelian}

Hasil pengujian menunjukan variabel promosi memiliki pengaruh positif dan signifikan terhadap keputusan pembelian pada KOI bubble tea, Hasil ini terbukti promosi KOI semakin meningkatkan terhadap keputusan pembelian. KOI bubble tea memiliki promosi yang dapat dijangkau oleh kalangan mahasiswa dengan keputusan pembelian yang sebanding dengan fitur-fitur aplikasi dan manfaat produknya yang sangat modern. Promosi merupakan elemen bauran pemasaran yang berfokus pada upaya menginformasikan, membujuk dan mengingatkan kembali konsumen akan merek dan produk perusahaan (Tjiptono 2015:387).

Hasil penelitian ini didukung penelitian yang dilakukan oleh Budianto (2019) dan Brata et al (2017), menyatakan bahwa promosi memiliki pengaruh positif dan signifikan terhadap keputusan pembelian. 


\section{Pengaruh Kualitas Produk terhadap Keputusan Pembelian}

Hasil pengujian menunjukan variabel kualitas produk memiliki pengaruh positif dan signifikan terhadap keputusan pembelian pada KOI bubble tea. Hal ini terbukti kualitas produk KOI semakin meningkatkan keputusan pembelian konsumen. Kualitas produk KOI terbukti mempunyai kinerja yang cukup disiplin dan produk tersebut sangat layak, karena semua produk yang dikeluarkan memiliki kualitas premium dengan fitur sangat menarik, selain itu mempunyai tingkat daya tahan yang lama seperti kualitas produk tersebut. Kualitas produk adalah karakteristik produk atau layanan yang sesuai dengan kemampuan nya untuk memenuhi kebutuhan pelanggan (Kotler dan Amstrong 2015:236).

Hasil penelitian ini didukung penelitian yang dilakukan oleh Nisa (2020), Budianto (2019), Anjani (2019), Nababan (2019), Fitria (2018) dan Brata et al (2017) menyatakan bahwa kualitas produk memliki pengaruh positif signifikan terhadap keputusan pembelian.

\section{Pengaruh Citra Merek Terhadap Keputusan Pembelian}

Variabel citra merek berpengaruh positif dan tidak signifikan terhadap keputusan pembelian pada KOI bubble tea. Hal ini terbukti bahwa citra merek KOI tidak berperan besar dalam meningkatkan keputusan pembelian. Citra merek KOI bubble tea mudah dikenali oleh masyarakat khususnya seluruh mahasiswa. Produk KOI memiliki citra yang akan membuat para penggunanya terlihat mewah dan ciri khas logo nya yang premium dan spesifikasi yang bisa dibilang titik unggul. Dengan kemampuan konsumen menurut Surachman (2008:13) menyatakan citra merek sebagian dari merek yang dapat dikenali namun tidak dapat diucapkan, seperti lambang, desain huruf atau warna tertentu, atau persepsi pelanggan atas sebuah yang ditandai dengan untuk mengetahui merek KOI bubble tea dari produk merek lainya.

Hasil penelitian ini didukung oleh Nisa (2020) dan Ayuningtyas (2016) menyatakan bahwa citra merek memiliki pengaruh positif signifikan terhadap keputusan pembelian.

\section{Pengaruh Promosi Terhadap Keputusan Pembelian Dimediasi Citra Merek}

Promosi merupakan salah satu variabel yang terdapat dalam bauran pemasaran yang memiliki peran penting untuk mengkomunikasikan keberadaan dan nilai produk kepada calon pelanggan. Berdasarkan hasil penelitian di atas dapat diketahui bahwa variabel promosi memiliki pengaruh positif dan signifikan terhadap citra merek. Sedangkan variabel citra merek memiliki pengaruh positif dan tidak signifikan terhadap keputusan pembelian.

Hasil penelitian ini mendukung penelitian Budianto (2019) dan Ayuningtyas (2016) yang menyimpulkan bahwa citra merek dapat memediasi hubungan antara promosi terhadap keputusan pembelian.

\section{Pengaruh Kualitas Produk Terhadap Keputusan Pembelian Dimediasi Citra Merek}

Kualitas produk adalah suatu kondisi dinamis yang berhubungan dengan produk, manusia/tenaga kerja, proses dan tugas, serta lingkungan yang memenuhi atau melebihi harapan pelanggan atau konsumen. Baik buruknya kualitas produk yang diberikan tergantung pada kemampuan penyedia jasa dalam memenuhi harapan pelanggannya secara konsisten. Maka dari itu kualitas produk menjadi hal penting yang harus diperhatikan serta dimaksimalkan agar mampu bertahan dan tetap dijadikan pilihan oleh pelanggan. Berdasarkan hasil penelitian di atas dapat diketahui bahwa variabel kualitas produk memiliki pengaruh positif dan signifikan terhadap citra merek. Sedangkan variabel citra merek memiliki pengaruh positif dan tidak signifikan terhadap keputusan pembelian. 
Hasil penelitian ini mendukung penelitian Budianto (2019), Anjani (2019), dan Nababan (2019) yang menyimpulkan bahwa citra merek dapat memediasi hubungan antara kualitas produk terhadap keputusan pembelian.

\section{Kesimpulan}

Promosi berpengaruh positif dan signifikan terhadap Citra Merek, artinya promosi yang dilakukan KOI bubble tea telah mampu menginformasikan keunggulan yang dimiliki dan dapat mempengaruhi konsumen untuk membeli produk serta meningkatkan konsumen untuk membeli produk yang dihasilkan tersebut. Kualitas Produk berpengaruh positif dan signifikan terhadap Citra Merek, artinya semakin tinggi kualitas produk yang digunakan oleh KOI maka akan semakin meningkat citra merek pada KOI bubble tea serta kemampuan suatu barang untuk memberikan hasil atau kinerja yang sesuai bahkan melebihi dari apa yang diinginkan pelanggan. Promosi berpengaruh positif dan signifikan terhadap Keputusan Pembelian, artinya promosi adalah suatu komunikasi informasi antara penjual dengan pembeli yang bertujuan untuk merubah sikap dan tingkah laku pembeli, yang tadinya tidak mengenal menjadi mengenal sehingga menjadi pembeli dan tetap mengingat produk tersebut. Kualitas Produk memiliki pengaruh positif dan signifikan terhadap Keputusan Pembelian, hal ini berarti semakin tinggi kualitas produk yang digunakan oleh KOI bubble tea maka akan semakin meningkatkan juga keputusan pembelian konsumen pada KOI bubble tea. Kualitas produk merupakan bentuk penilaian atas produk yang akan dibeli, apakah sudah memenuhi apa yang diharapkan konsumen. Citra Merek berpengaruh positif dan tidak signifikan terhadap Keputusan Pembelian, artinya citra merek sebagian dari merek yang dapat dikenali namun tidak dapat diucapkan, seperti lambang, desain huruf atau warna tertentu, atau persepsi pelanggan atas sebuah yang ditandai dengan untuk mengetahui merek KOI bubble tea dari produk merek lainnya. Promosi memiliki pengaruh signifikan terhadap Keputusan Pembelian dengan dimediasi Citra Merek, artinya terdapat jalur yang menghubungkan antara variabel promosi terhadap keputusan pembelian melalui citra merek. Kualitas Produk berpengaruh signifikan terhadap Keputusan Pembelian dimediasi Citra Merek, artinya terdapat adanya jalur yang menghubungkan antara variabel kualitas produk terhadap keputusan pembelian melalui citra merek.

\section{Daftar Pustaka}

Alma, B. 2011. Manajemen Pemasaran dan Pemasaran Jasa, Alfabeth, Bandung.

Anjani. 2019. Pengaruh Kualitas Produk dan Iklan terhadap Keputusan Pembelian dengan Brand Image sebagai Intervening: (Studi pada konsumen minuman ringan bersoda merek coca cola di kota Semarang). Jurnal Administrasi Bisnis. Semarang.

Ayuningtyas. 2016. Pengaruh Kualitas Produk dan Iklan terhadap Keputusan Pembelian dengan Brand Image sebagai Intervening: (Studi pada konsumen minuman ringan bersoda merek coca cola di kota Semarang). Jurnal Administrasi Bisnis. Semarang.

Brata. 2017. The Influence of Quality Products, Price, Promotion, and Location to Product Purchase Decisions. Saudi J. Bus. Management. Stud. Vol-2, Iss-4B : 433-445.

Budianto, Y. P. dan Budiatmo. A. 2019. Pengaruh Promosi dan Kualitas Produk terhadap Keputusan Pembelian dengan Brand Image sebagai Intervening: (Studi pada Konsumen Susu Frisian Flag Kemasan Siap Minum Purefarm di Kota Madiun). Diponegoro. Journal of Social and Politic. Hal. 1-10.

Djaslim, S. 2011. Unsur-Unsur Inti Pemasaran dan Manajemen Pemasaran, Bandung. 
Fitria. V. 2018. Pengaruh Gaya Hidup dan Kualitas Produk terhadap Keputusan Pembelian Dimediasi Citra Merek: (Studi Kasus J-Co Suzunya Mall Rantauprapat). Vol 5 No. 1. Furchan, A. 2010. Pengantar Penelitian dalam Pendidikan, Usaha Nasional, Surabaya.

George R. T. 2013. Dasar-dasar Manajemen, CV. Alfabeta, Bandung.

Ghozali. 2011. Aplikasi Analisis Multivariate dengan Program SPSS. Cetakan kedelapan. Universitas Diponegoro Semarang.

Irawan, B. S. 2011. Manajemen Pemasaran Modern, Liberty, Yogyakarta.

Kotler, P. dan Keller, K. L. 2012. Manajemen Pemasaran. Edisi 12. Jakarta: Erlangga.

Kotler, P \& Armstrong. 2010. Principles of Marketing, thirteen edition. New Jersey: Prentice-Hall, Inc.

Marhari, O. Y. 2012. Manajemen Bisnis Modern Ala Nabi Muhammad, AlMaghfiroh, CV. Diponegoro, Bandung.

Nazir. 2011. Metodologi Penelitian, Ghalia Indonesia, Bogor.

Nababan. 2019. Pengaruh Kualitas Produk dan Word of Mouth terhadap Keputusan Pembelian dengan Brand Image sebagai Intervening: (Studi pada Pengguna Fladeo Ladies di Jakarta). Diponegoro Journal of Social and Politic. Volume 8, Nomor 4, Hal. 58-69.

Nisa, K. 2020. Pengaruh Label Halal, Celebrity Endorser, dan Kualitas Produk terhadap Keputusan Pembelian dengan Brand Image sebagai Intervening. E-Jurnal Manajemen, 195.

Saladin, D. 2013. Manajemen Pemasaran Ringkasan Praktis, Teori, Aplikasi, dan Tanya Jawab, Linda Karya, Bandung.

Sanusi, A. 2015. Manajemen Strategi. Pemasaran, CV Pustaka Setia, Bandung.

Sugiyono. 2010. Metode Penelitian Pendekatan Kuantitatif, Kualitatif, dan R\&D. Bandung: Alfabeta.

Tjiptono, F. 2012. Strategi Pemasaran, Andi Offset, Yogyakarta.

William J. 2015. Prinsip alih bahasa Erlangga, Jakarta. 